Lina $\mathrm{YU}^{a}$, Kazuyoshi SAIDA ${ }^{b}$, Kazutoshi NISHIMOTO ${ }^{c}$

\title{
Extended application of hardness prediction system for temper bead welding of A533B steel to various low-alloy steels
} Proširena primena sistema za predviđanje tvrdoće kod zavarivanja čelika A533B za razne niskolegirane čelike

\section{NASTAVAK IZ PREDHODNOG BROJA \\ 2.deo}

(a)
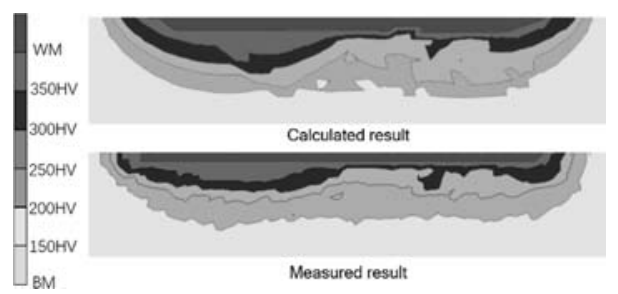

\section{CONTINUED FROM PREVIOUS ISSUE} Part 2

(b)

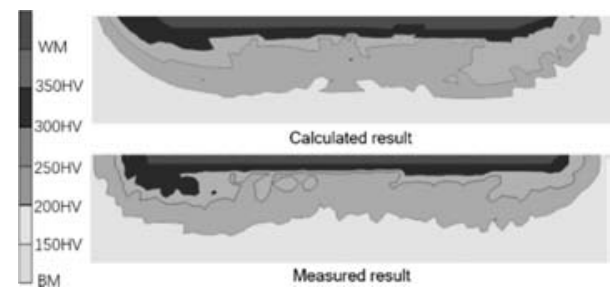

Fig. 10 Hardness distribution comparison of 1.5\%Ni steel: (a) 1layer-3pass welding and (b) 6layer-21pass welding SI. 10 Upoređenje raspodele tvrdoće za čelik 1.5\% Ni: (a) 1 sloj-3 prolaza $i$ (b) 6 slojeva-21 prolaz
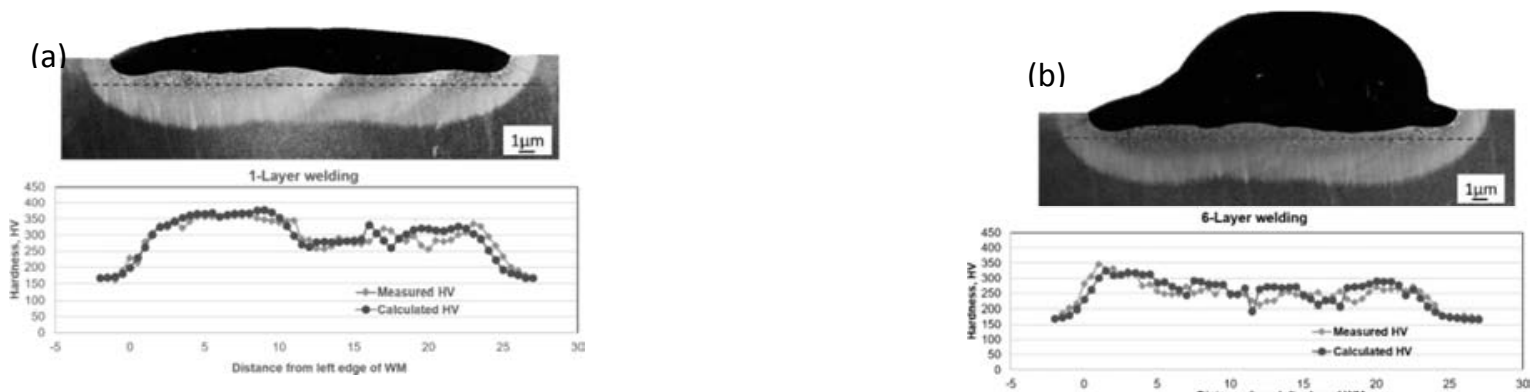

Fig. 11 Hardness comparison after 1-Layer and 6-Layer welding of 1.5\%Ni steel: (a) 1layer-3pass welding and (b) 6layer-21pass welding

SI. 11 upoređenje tvrdoća posle 1-slojnog i 6-slojnog zavarivanja čelika 1.5\%Ni: (a) 1 sloj-3 prolaza i (b) 6 slojeva21 prolaz

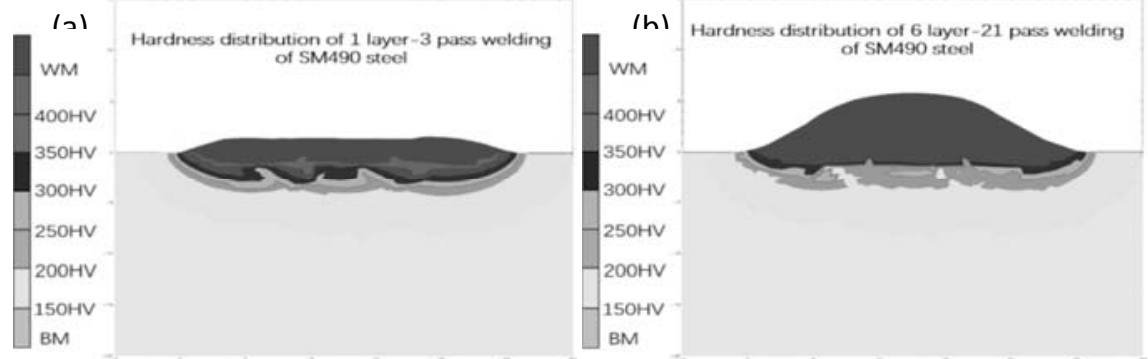

Fig. 12 Predicted hardness distribution of SM490 steel: (a) 1layer-3pass welding and (b) 6layer-21pass welding SI. 12 Predviđena raspodela tvrdoća za čelik SM490: (a) 1 sloj-3 prolaza i (b) 6 slojeva -21prolaz

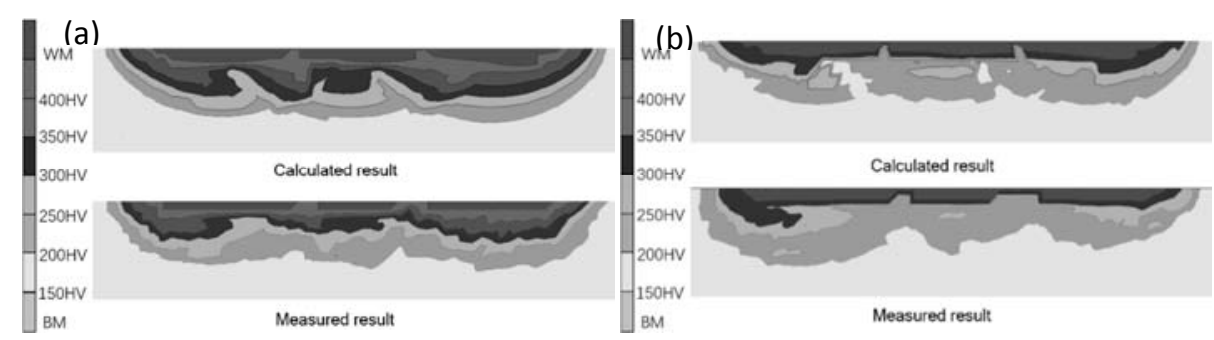

Fig. 13 Hardness distribution comparison of SM490 steel: (a) 1layer-3pass welding and (b) 6layer-21pass welding SI. 13 Upoređenje raspodele tvrdoće čelika SM490: (a) 1 sloj-3prolaza i (b) 6 slojeva -21 prolaz 


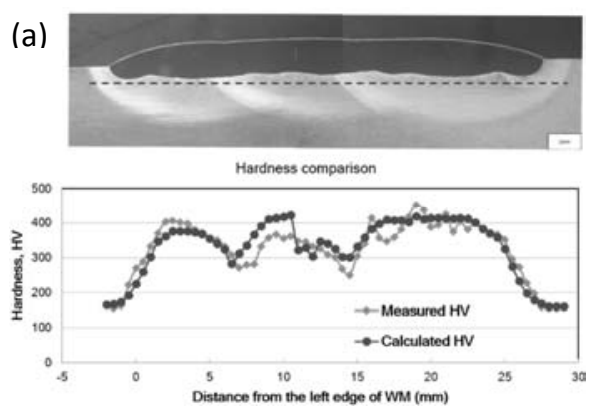

(b)

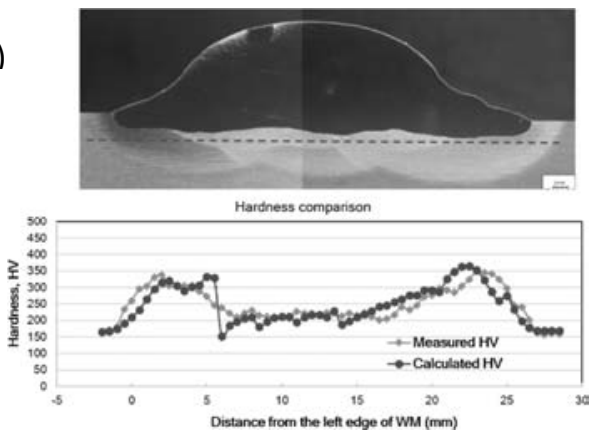

Fig. 14 Hardness comparison after 1Layer and 6Layer welding of SM490 steel: (a) 1layer-3pass welding and (b) 6layer-21pass welding

SI. 14 Upoređenje tvrdoće posle 1 slojnog i 6 slojnog zavarivanja čelika SM490: (a) 1sloj -3 prolaza i (b) 6 slojeva21 prolaz

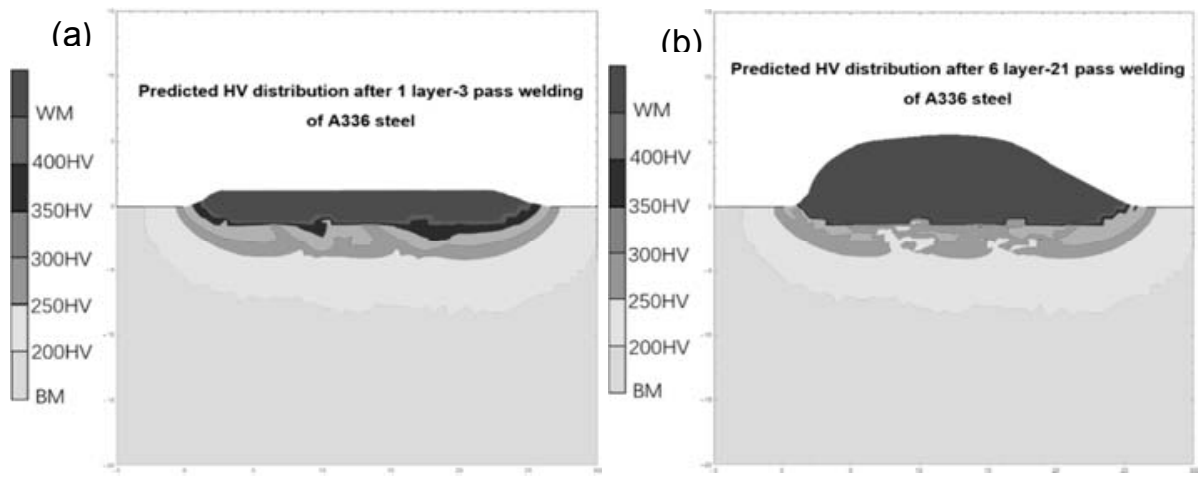

Fig. 15 Predicted hardness distribution of A336 steel: (a) 1layer-3pass welding and (b) 6layer-21pass welding

SI. 15 Predviđena raspodela tvrdoće kod čelika A336: (a) 1sloj-3 prolaza i (b) 6 slojeva -21 prolaz
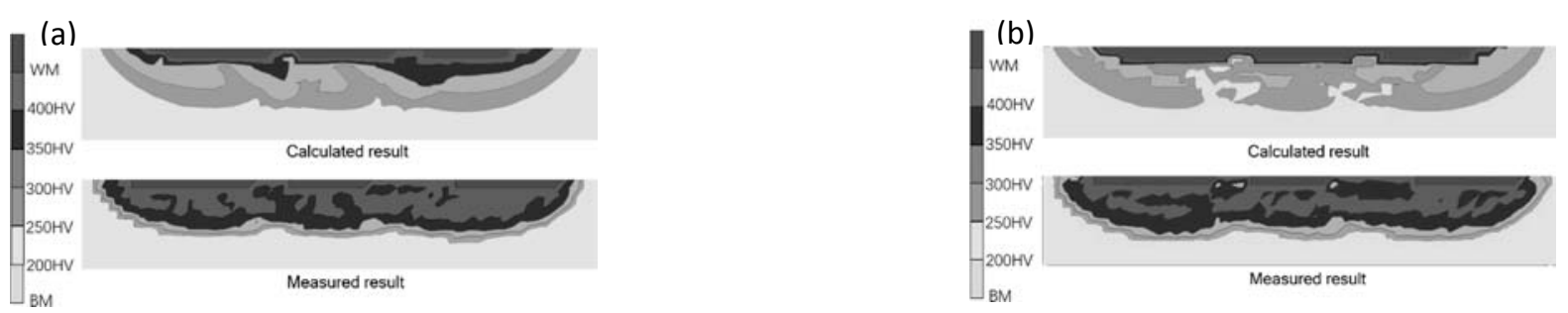

Fig. 16 Hardness distribution comparison of A336 steel: (a) 1layer-3pass welding and (b) 6layer-21pass welding SI. 16 Upoređenje raspodele tvrdoće čelika A336: (a) 1 sloj-3 prolaza i (b) 6 slojeva -21 prolaz
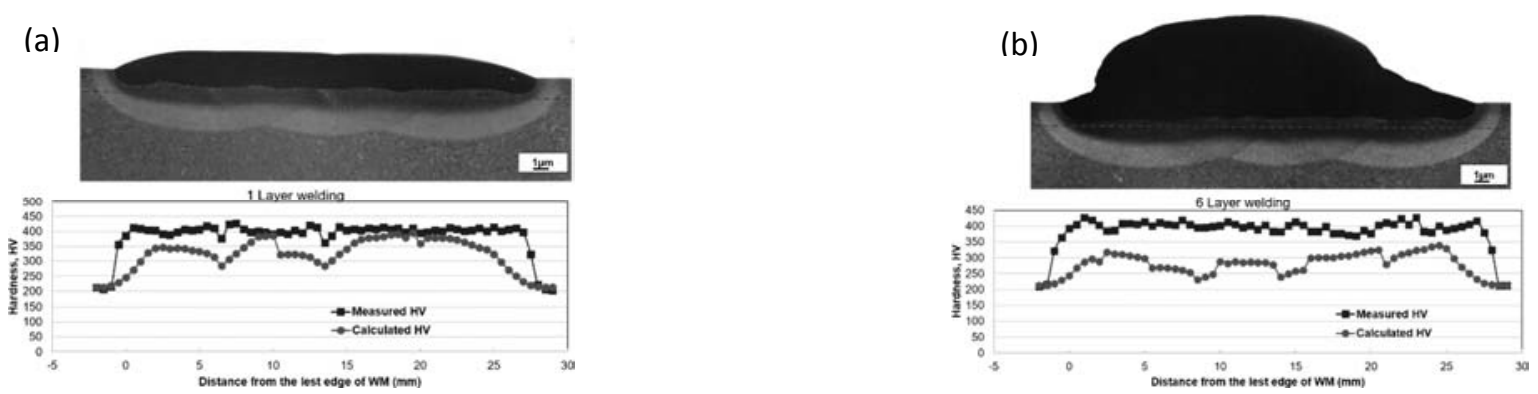

Fig. 17 Hardness comparison after 1Layer and 6Layer welding of A336 steel: (a) 1layer-3pass welding and (b) 6layer-21pass welding

SI. 17 Upoređenje tvrdoće posle 1 slojnog i 6 slojnog zavarivanja čelika A336: (a) 1 sloj-3 prolaza i (b) 6 slojeva-21 prolaz 


\begin{tabular}{cccc}
\hline Steel & 1-layer & 6-layer & Validity \\
\hline A508 & 0.92 & 0.83 & $\circ$ \\
$\mathbf{1 . 5 \% N i}$ & 0.91 & 0.82 & $\circ$ \\
SM490 & 0.89 & 0.81 & $\circ$ \\
\hline A336 & 0.55 & 0.19 & $\mathbf{x}$
\end{tabular}

Table 3. Correlation coefficient between the predicted hardness and measured hardness

Tabela 3. Koeficijent korelacije između predviđene i izmerene tvrdoće

\section{Discussion of the extended hardness prediction method}

Fig. 18 illustrates the relationship between hardness after temper and LMP of 5 kinds of steel. It can be found that the hardness of $\mathrm{A} 508,1.5 \% \mathrm{Ni}$, SM490 steels after temper have a good linear relationship with LMP same to the original A533B steel, indicating that $A 508,1.5 \% \mathrm{Ni}$, SM490 steels are the steels without secondary hardening. However, there is no linear relationship between the hardness of A336 steel and LMP, meaning that A336 steel is the steel with secondary hardening. It follows that the proposed hardness prediction method is useful and effective for estimating the tempering effect in temper bead welding of the lowalloy steels without secondary hardening, expect for the low-alloy steels with secondary hardening.

As shown in Table 3 , the correlation coefficient between the predicted hardness and the experimentally measured hardness of A508, $1.5 \% \mathrm{Ni}$, SM490 steels also changed from high to low. Based on the microstructure observation at different peak temperatures, the schematic illustration of phase retransformation of 4 kinds of steel can be obtained as illustrated in Fig. 19. When the peak temperature is higher than $\mathrm{Ac}_{3}$ or lower than $\mathrm{Ac}_{1}$, both phase composition and grain size are similar for all kinds of steel. However, when the peak temperature is between Ac1 and Ac3, both phase composition and grain size of A508 steel is similar with A533B steel, while there are little different for $1.5 \% \mathrm{Ni}$ and SM490 steels. This explains the difference of the correlation coefficient of the A508, $1.5 \% \mathrm{Ni}$, SM490 steels. But because the temperature range between Ac1 and Ac3 is very narrow, the hardness in the whole HAZ zone have been successfully predicted using the proposed method. Therefore, the hardness of the other low-alloy steels without secondary hardening can be predicted by using the extended hardness database of A533B, from the view of engineering. Above all, the low-alloy steel has been classified as Group A D as illustrated in Fig. 20. Group A C are the low-alloy steels without secondary hardening, while Group D is the low-alloy steels with secondary hardening. For the Group $A \sim C$ without secondary hardening, the currently proposed extended method is effective for estimating the

\section{Diskusija o proširenoj metodi predviđanja tvrdoće}

SI. 18 prikazuje odnos između tvrdoće nakon otpuštanja i LMP kod 5 vrsta čelika. Može se utvrditi da tvrdoća čelika A508, 1,5\% Ni, SM490 čelika ima dobru linearnu vezu sa LMP-om isto kao i originalni čelik A533B, što ukazuje da su A508, $1,5 \% \quad \mathrm{Ni}, \quad$ SM490 čelici bez sekundarnog otvrdnjavanja. Međutim, ne postoji linearni odnos između tvrdoće čelika A336 i LMP, što znači da je čelik A336 čelik sa sekundarnim otvrdnjavanjem. Iz toga sledi da je predložena metoda predviđanja tvrdoće korisna i efikasna za procenu efekta otpuštanja pri zavarivanju zavara za otpuštanje niskolegiranih čelika bez sekundarnog otvrdnjavanja, a očekujemo i kod niskolegiranih čelika sa sekundarnim otvrdnjavanjem.

Kao što je prikazano u Tabeli 3 , koeficijent korelacije između predviđene tvrdoće i eksperimentalno izmerene tvrdoće čelika A508, $1,5 \% \mathrm{Ni}$, SM490 takođe se menjao od visoke do niske. $\mathrm{Na}$ osnovu posmatranja mikrostrukture pri različitim vršnim temperaturama, šematski prikaz fazne retransformacije četiri vrste čelika može se postićii kao što je prikazano na slici 19. Kada je vršna temperatura viša od Ac3 ili niža od Ac1, i fazni sastav i veličina zrna slične su za sve vrste čelika. Međutim, kada je vršna temperatura između Ac1 i Ac3, i fazni sastav i veličina zrna čelika A508 su slični čeliku A533B, dok su za čelike 1,5\% Ni i SM490 malo različite. Ovo objašnjava razliku koeficijenta korelacije čelika A508, 1,5\% Ni, SM490 čelika. Ali budući da je temperaturni opseg između Ac1 i Ac3 vrlo uzak, tvrdoća u celoj ZUT uspešno se predviđa pomoću predložene metode. Stoga se tvrdoća ostalih niskolegiranih čelika bez sekundarnog otvrdnjavanja može predvidjeti upotrebom proširene baze podataka o tvrdoći A533B, sa stanovišta tehnike.

Povrh svega, niskolegirani čelik je klasifikovan kao grupa A-D kao što je prikazano na slici 20. Grupa A-C su niskolegirani čelici bez sekundarnog otvrdnjavanja, dok je grupa $D$ niskolegirani čelici sa sekundarnim otvrdnjavanjem. Za grupu $\mathrm{A} \sim \mathrm{C}$ bez sekundarnog otvrdnjavanja, trenutno predložena proširena metoda je efikasna za procenu efekta otpuštanja tokom zavarivanja zavara za otpuštanje. 
tempering effect during temper bead welding. Thus, the appropriate welding conditions would be able to optimize before the actual welding.

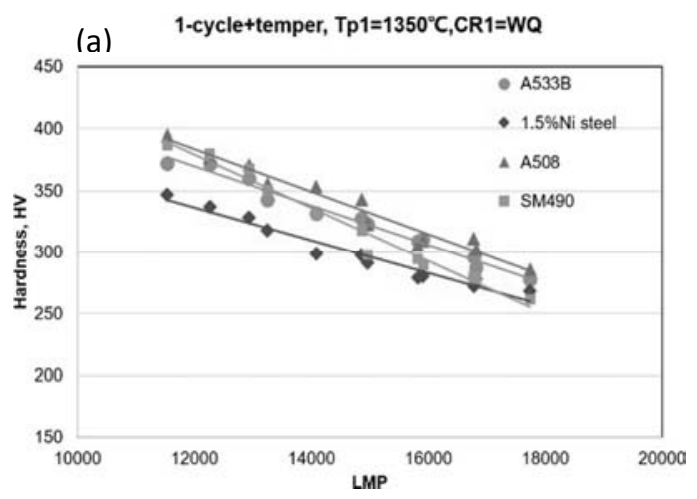

Stoga bi se odgovarajući uslovi zavarivanja mogli optimizirati pre stvarnog zavarivanja.

(b) 1-cycle+temper, $T_{p 1}=1350^{\circ} C, C R_{1}=W Q$

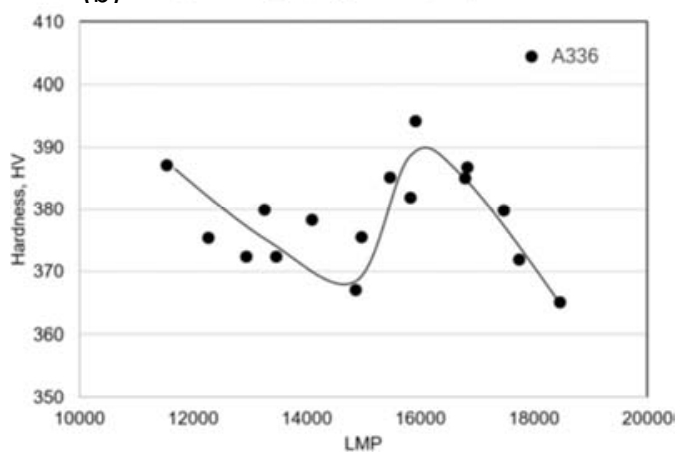

Fig. 18 Relationship between hardness after temper and LMP of 5 kinds of steels

SI. 18 Međusobni odnos između tvrdoća posle otpuštanja i LMP za 5 vrsta čelika

1-cycle $C R 1=W Q$
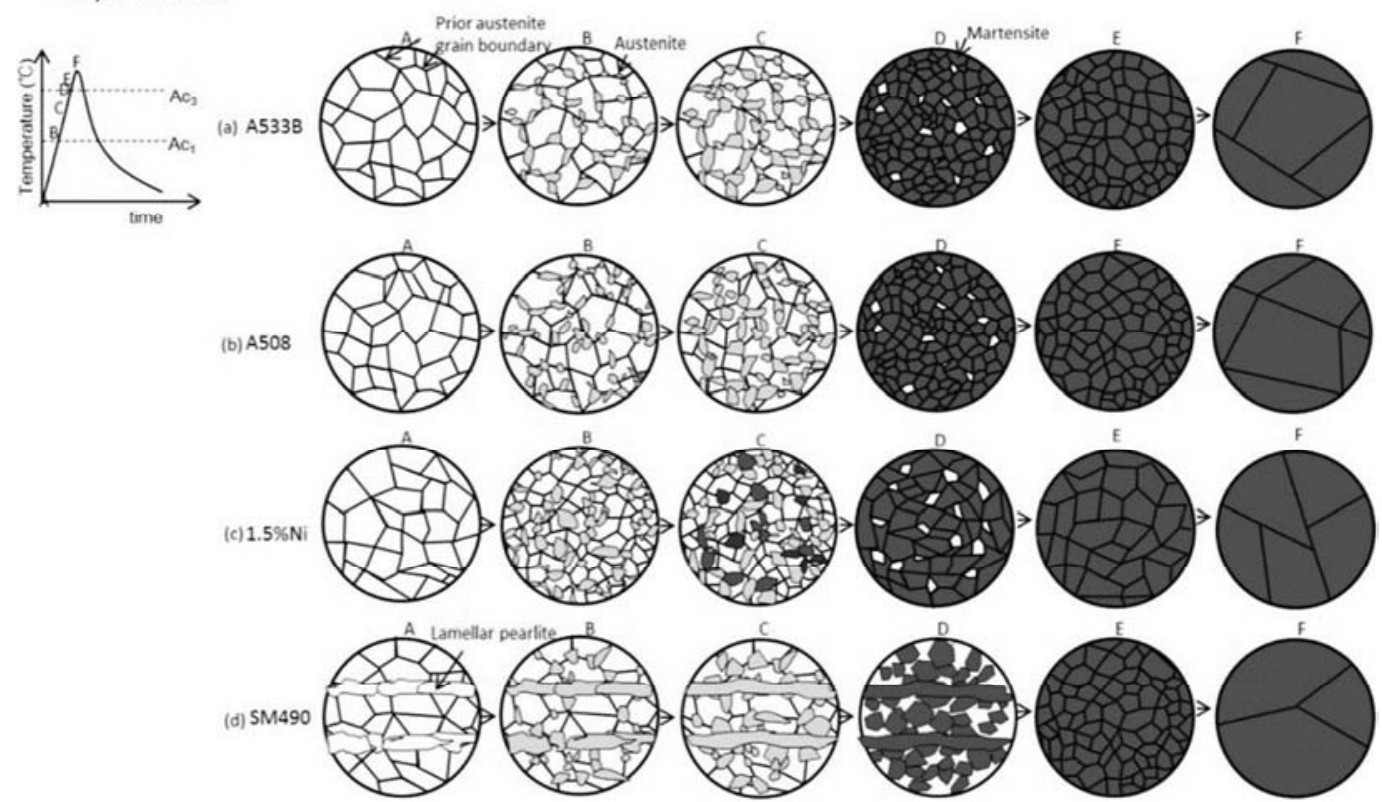

Fig. 19 Schematic illustration of transformation

SI. 19 Šematska ilustracija transformacije

\section{Conclusions}

In the present study, the generalized hardness prediction method applicable for the other low-alloy steels has been conducted by utilizing the presented hardness data-base of A533B steel.

1) Using the proposed extended hardness prediction method, hardness distribution in HAZ of temper bead welding for A508, $1.5 \% \mathrm{Ni}$ and SM490 steels were calculated based on the thermal cycles simulated by finite element method.

2) The predicted hardness was in good accordance with the experimentally measured result for A508, $1.5 \% \mathrm{Ni}$, SM490 steels expect for A336 steel. It followed that the bead welding for the low-alloy steels without secondary hardening.

\section{Zaključci}

U ovom istraživanju, sprovedena je opšta metoda predviđanja tvrdoće koja se primenjuje za ostale niskolegirane čelike korišćenjem predstavljene baze podataka o tvrdoći A533B čelika.

1) Korišćenjem predložene proširene metode predviđanja tvrdoće, raspodela tvrdoće u ZUT zavara za otpuštanje za čelike A508, 1,5\% Ni i SM490 izračunata je na osnovu toplotnih ciklusa simuliranih metodom konačnih elemenata.

2) Predviđena tvrdoća bila je u dobroj usaglašenosti $s$ eksperimentalno izmerenim rezultatom za čelike A508, $1,5 \% \mathrm{Ni}, \mathrm{SM} 490$ a očekuje se i za čelik A336. Iz toga je usledilo zavarivanje zavara kod niskolegiranih čelika bez sekundarnog otvrdnjavanja. 
3) Through this method, the hardness of low-alloy steels without secondary hardening could be predicted before the actual welding, thus the appropriate welding conditions would be able to optimize before actual welding, which is very useful for the repair welding for large structures
3) Ovom metodom se može predvideti tvrdoća niskolegiranih čelika bez sekundarnog otvrdnjavanja pre stvarnog zavarivanja, ako bi se odgovarajući uslovi zavarivanja mogli optimizirati pre stvarnog zavarivanja, što je vrlo korisno za reparaturno zavarivanje velikih konstrukcija

\section{References Bibliografija}

[1] N. Yurioka and Y. Horii, Recent developments in repair welding technologies in Japan, Science and Technology of Welding \& Joining, 11 (2006), 255264.

[2] J. Liao, K. Ikeuchi and F. Matsuda, Toughness Investigation on Simulated Weld HAZs of SQV-2A Pressure Vessel Steel, Nuclear Engineering and Design, 183 (1998), 9-20.

[3] L. Yu, Y. Nakabayashi, M. Sasa, S. Itoh, K. Saida, M. Mochizuki, K. Nishimoto, M. Kameyama, S. Hirano and N. Chigusa, Neural Network Prediction of Hardness in HAZ of Temper Bead Welding using the Proposed Thermal Cycle Tempering Parameter (TCTP), ISIJ International, 51 (2011), 1506-1515.

[4] L. Yu, K. Saida, M. Mochizuki, M. Kameyama, N. Chigusa and K. Nishimoto, Hardness Prediction of HAZ in Temper Bead Welding by Non-Consistent Layer Technique, E-Journal of Advanced Maintenance, 6 (2014), 34-47.

[5] L. Yu, K. Saida, S. Hirano, N. Chigusa, M. Mochizuki, and K. Nishimoto, Application of neural network based hardness prediction method to HAZ of A533B steel produced by laser temper bead welding, Welding in the World, 61(2017), 483- 498.

[6] R. Viswanathan, D. W. Gandy and S. J. Findlan, Temper bead welding of P-Nos. 4 and 5 materials, EPRI TR-111757, EPRI, Palo Alto, CA, USA, December 1998.
[7] L. Yu, M. SaSa, K. Ohnishi, M. Kameyama, S. Hirano, N. Chigusa, T. Sera, K. Saida, M. Mochizuki and K. Nishimoto, Neural NetworkBased Toughness Prediction in HAZ of Low- Alloy Steel Produced by Temper Bead Welding Repair Technology, Science and Technology of Welding and Joining, 18 (2013), 120-134.

[8] D. Deng, H. Murakawa and M. Shibahara, Investigations on welding distortion in an asymmetrical curved block by means of numerical simulation technology and experimental method, Computational Materials Science, 48 (2010), 187194.

[9] D. Casasent and X. Chen, Radial Basis Function Neural Networks for Nonlinear Fisher Discrimination and Neyman- Pearson Classification, Neural Networks, 16 (2003), 529535.

[10] H. K. D. H. Bhadeshia, R. C. Dimitriu, S. Forsik, J. H. Pak and J. H. Ryu, Performance of neural networks in materials science, Materials Science and Technology, 25-4(2009), 504- 510.

[11] T. Cool, H. K. D. H. Bhadeshia and D. J. C. MacKay, The yield and ultimate tensile strength of steel welds, Materials Science and Engineering A, 223(1997), 186-20 0. 